\title{
The effect of a high forage diet and different fat sources on rumen fermentation in vitro*
}

\author{
D. Jaľ̌ , A. Potkański², M. Szumacher-Strabel ${ }^{2}$, J. Kowalczyk ${ }^{3}$ \\ and A. Cieślak ${ }^{2}$ \\ ${ }^{1}$ Institute of Animal Physiology, Slovak Academy of Sciences \\ Soltesovej 4-6, 04001 Košice, Slovak Republic \\ ${ }^{2}$ The August Cieszkowski Agricultural University of Poznań, \\ Department of Animal Nutrition and Feed Management \\ Wotyńska 33, 60-637 Poznań, Poland \\ ${ }^{3}$ The Kielanowski Institute of Animal Physiology and Nutrition, Polish Academy of Sciences \\ 05-110 Jabtonna, Poland
}

\begin{abstract}
The experiment was carried out in a Rusitec system (rumen simulation technique). The effect of a high forage diet ( $60 \%$ fresh lucerne $+40 \%$ maize) and different fat sources (linseed LO, rapeseed RO, fish FO oils, $5 \%$ wt.wt ${ }^{-1}$ ) on rumen fermentation was studied. The experiment lasted 13 days. To ensure a steady-state within the fermentation Rusitec vessels a 7-day adaptation period preceded the 6-day collection period. Fermentation vessels were supplied daily with the high forage diet (control) and a 5\% addition of LO, RO or FO. Supplementing oil (LO, RO, FO) did not affect some of the basal parameters of rumen fermentation $(\mathrm{pH}$, total VFA production, dry matter and detergent fibre digestibility) in comparison with the control. The oils significantly reduced the $\mathrm{mol} \%$ of acetate (LO, FO; $\mathrm{P}<0.001 ; \mathrm{RO} ; \mathrm{P}<0.05$ ), n-butyrate (FO; $\mathrm{P}<0.01$ ), and $\mathrm{A} / \mathrm{P}$ ratio (LO, FO; $\mathrm{P}<0.001$ ) and increased the mol\% of propionate (LO, FO; $\mathrm{P}<0.001)$. Rapeseed oil supplementation slightly affected these parameters of rumen fermentation. The oils (LO, FO, RO) supplemented to the high forage diet had no effect on the efficiency of microbial protein synthesis.
\end{abstract}

KEY WORDS: artificial rumen, lucerne, maize, oils, rumen fermentation

\section{INTRODUCTION}

Understanding the influence of dietary fat sources on rumen metabolism is important. Changing rumen fermentation by including fatty acids in diets may be

\footnotetext{
* Supported by the Grant Agency of the Slovak Academy of Sciences, Grant No. 2/6174/6 and the State Committee for Scientific Research (Poland), Grant No. 3 P06Z 05923

${ }^{1}$ Corresponding author: e-mail: jalcd@saske.sk
} 
possible, but results carried out under in vitro conditions should be confirmed by in vivo findings (Hristov et al., 2004). The type of diet fed to ruminants influences rumen fermentation, and the level of forage in the diet determines the type of fermentation process. Moreover, dietary fats may inhibit rumen microbial synthesis or fibre digestion. In this study, the effect of a high forage diet (fresh lucerne plus maize 60:40\%) and of the diet supplemented with rapeseed, linseed or fish oil (5\% $\left.\mathrm{wt} \cdot \mathrm{wt}^{-1}\right)$ on rumen fermentation in an artificial rumen was studied.

\section{MATERIAL AND METHODS}

\section{Animals and diets}

The rumen simulation technique and rumen fluid supply of Rusitec equipment and chemical composition of feed was described by Jalč et al. (2006a).

The animals were fed with fresh lucerne ( $960 \mathrm{~g}$ of DM) and crushed maize (240 $\mathrm{g}$ of DM) daily. In the Rusitec, all fermentation vessels were supplied with $18 \mathrm{~g}$ (5.4 $\mathrm{g} \mathrm{DM})$ of fresh lucerne and $4.13 \mathrm{~g}(3.6 \mathrm{~g} \mathrm{DM})$ of crushed maize together with the addition of, $5 \% \mathrm{wt}^{\cdot} \mathrm{wt}^{-1}$ : LO, RO or FO.

\section{Measurements and chemical analyses}

The experiment in the Rusitec lasted 13 days. To ensure a steady state within the vessels a 7-day adaptation period preceded the 6-day collection period. On days 8-13 samples were collected and analysed: for volatile fatty acids (VFA), nitrogen and ammonia nitrogen $\left(\mathrm{NH}_{3}-\mathrm{N}\right)$ in effluent; dry matter, NDF and ADF, ash and nitrogen in feed and residual feed (undigested feed samples), respectively. Other fermentation variables, i.e. fermentation efficiency (E), organic matter fermented (OMF), nitrogen incorporated by microflora $\left(\mathrm{N}_{\mathrm{M}}\right)$, efficiency of microbial protein synthesis (EMS) were calculated according to the stoichiometry of rumen fermentation. Detailed procedures were described in a previous study (Jalč and Čertík, 2005).

\section{Statistical analysis}

Means of results from treatments were compared by one-way analysis of variance (ANOVA). Treatment means were statistically compared by the TukeyKramer multiple comparison test. The tables give the group means and the standard error of the mean. 


\section{RESULTS AND DISCUSSION}

The fermentation of the diets was carried out at $\mathrm{pH}$ 6.88-6.97 and the $\mathrm{pH}$ values were slightly lower in all oil-supplemented diets compared with the control (Table 1). The concentration of $\mathrm{NH}_{3}-\mathrm{N}$ remained about 30-36 mg $\cdot 100 \mathrm{ml}^{-1}$ and was not affected by oil supplementation (Table 1). After $48 \mathrm{~h}$ of incubation in fermentation fluid the rumen degradation of dry matter (DMD)

Table 1. Effect of the diet consisting of fresh lucerne and maize (60:40\%) and supplemented with different oils on the rumen fermentation pattern in a Rusitec (n-6)

\begin{tabular}{|c|c|c|c|c|}
\hline \multirow{2}{*}{ Item } & \multicolumn{4}{|c|}{ The type of added oil $\left(5 \% \mathrm{wt} \cdot \mathrm{wt}^{-1}\right)$} \\
\hline & control $^{\mathrm{a}}$ & $\mathrm{LO}^{\mathrm{b}}$ & $\mathrm{RO}^{\mathrm{c}}$ & $\mathrm{FO}^{\mathrm{c}}$ \\
\hline $\mathrm{pH}$ & $6.97 \pm 0.05$ & $6.88 \pm 0.04$ & $6.96 \pm 0.05$ & $6.95 \pm 0.04$ \\
\hline DMD, \% & $81.44 \pm 2.14$ & $78.59 \pm 2.32$ & $79.37 \pm 2.16$ & $77.57 \pm 2.32$ \\
\hline NDF, $\%$ & $83.86 \pm 2.41$ & $81.41 \pm 2.05$ & $83.24 \pm 2.12$ & $81.11 \pm 1.92$ \\
\hline $\mathrm{ADF}, \%$ & $81.55 \pm 2.36$ & $77.63 \pm 2.12$ & $82.71 \pm 1.95^{\mathrm{d}}$ & $76.65 \pm 2.52$ \\
\hline Hemicellulose, $\%$ & $86.18 \pm 2.10$ & $86.34 \pm 2.15$ & $83.81 \pm 2.45$ & $87.05 \pm 2.02$ \\
\hline Cellulose, $\%$ & $83.86 \pm 2.45$ & $84.65 \pm 2.12$ & $87.17 \pm 2.32$ & $83.12 \pm 2.41$ \\
\hline $\mathrm{NH}_{3}-\mathrm{N}, \mathrm{mg} \cdot 100 \mathrm{ml}$ & $33.37 \pm 0.86$ & $30.53 \pm 0.85$ & $34.18 \pm 0.92$ & $35.99 \pm 0.91^{\mathrm{b}}$ \\
\hline $\mathrm{VFA}, \mathrm{mmol}^{\prime}$ day $^{-1}$ & $43.45 \pm 2.02$ & $42.62 \pm 1.84$ & $44.02 \pm 2.01$ & $43.64 \pm 2.12$ \\
\hline Acetate & $25.93 \pm 1.42$ & $20.11 \pm 1.65^{\mathrm{a}}$ & $25.70 \pm 1.42^{\mathrm{b}}$ & $24.45 \pm 1.81^{\mathrm{b}}$ \\
\hline Propionate & $8.26 \pm 0.29^{\mathrm{b}, \mathrm{d}}$ & $11.78 \pm 0.36^{\mathrm{c}}$ & $8.78 \pm 0.46^{\mathrm{d}}$ & $11.20 \pm 0.41$ \\
\hline n- butyrate & $5.78 \pm 0.09^{\mathrm{d}}$ & $5.52 \pm 0.11$ & $5.55 \pm 0.08$ & $4.22 \pm 0.11^{\mathrm{c}}$ \\
\hline $\mathrm{A} / \mathrm{P}$ ratio & $3.15 \pm 0.07^{\mathrm{b}, \mathrm{d}}$ & $1.72 \pm 0.05^{\mathrm{c}, \mathrm{d}}$ & $2.95 \pm 0.06^{\mathrm{d}}$ & $2.19 \pm 0.07$ \\
\hline Acetate, $\mathrm{mol} \%$ & $59.47 \pm 0.20^{\mathrm{b}, \mathrm{c}, \mathrm{d}}$ & $47.16 \pm 0.33^{\mathrm{c}, \mathrm{d}}$ & $58.35 \pm 0.26^{\mathrm{d}}$ & $56.03 \pm 0.30$ \\
\hline Propionate, $\mathrm{mol} \%$ & $18.92 \pm 0.45^{\mathrm{b}, \mathrm{d}}$ & $27.71 \pm 1.14^{\mathrm{c}}$ & $19.88 \pm 0.75^{\mathrm{d}}$ & $25.67 \pm 0.49$ \\
\hline n-butyrate, $\mathrm{mol} \%$ & $13.26 \pm 0.51$ & $12.93 \pm 0.65$ & $12.69 \pm 0.92$ & $9.69 \pm 0.58^{a, b, c}$ \\
\hline $\mathrm{E}, \%$ & $74.67 \pm 0.46^{\mathrm{b}, \mathrm{d}}$ & $79.19 \pm 0.41^{\mathrm{c}, \mathrm{d}}$ & $75.09 \pm 0.38^{\mathrm{d}}$ & $77.16 \pm 0.42$ \\
\hline OMF, g $\cdot$ day $^{-1}$ & $4.24 \pm 0.15$ & $4.23 \pm 0.16$ & $4.25 \pm 0.19$ & $4.09 \pm 0.18$ \\
\hline $\mathrm{N}_{\mathrm{M}}, \mathrm{mg} \cdot$ day $^{-1}$ & $89.59 \pm 3.92$ & $103.76 \pm 3.86$ & $95.74 \pm 4.25$ & $97.57 \pm 4.28$ \\
\hline EMS, $\mathrm{mg} \cdot \mathrm{g}^{-1}$ & $21.46 \pm 1.02$ & $24.69 \pm 1.18$ & $22.55 \pm 1.21$ & $24.07 \pm 1.14$ \\
\hline
\end{tabular}

LO - linseed oil; RO - rapeseed oil; FO - fish oil; DMD - dry matter digestibility; NDF - neutral detergent fibre; ADF - acid detergent fibre; $\mathrm{E}$ - energetic efficiency of volatile fatty acids; OMF - organic matter fermented; $\mathrm{N}_{\mathrm{M}}$ - nitrogen incorporated by microflora; EMS efficiency of microbial protein synthesis; \pm SEM (standard error of mean); values with the same letter are not significantly different $(\mathrm{a}, \mathrm{b}, \mathrm{c}, \mathrm{d}, \mathrm{P}<0.05$ )

was slightly reduced in the oil-supplemented diets. The apparent digestibility of dry matter and organic matter also did not significantly differ when sheep were fed fat (60 $\mathrm{g} \cdot \mathrm{kg}^{-1}$ fatty acids) from different fat sources, i.e. linseed, fish oil, linfish (linseed + fish oil; Wachira et al., 2000). The digestibility of NDF, ADF, hemicellulose and cellulose in the fresh lucerne-maize (60:40\%) diet did not differ significantly among the control and oil-supplemented diets (Table 1). From the three oils used in these experiments, mainly LO and FO showed slight depressive effects on fibre digestion. Some authors (e.g., Wachira et al., 2000) reported negative effects of polyunsaturated fatty acids (PUFA), particularly fish oil, on fibre digestion in sheep and beef cattle. 
Most studies found a reduction in acetate production after supplementing oil to diets. In our study, LO significantly, FO and RO slightly $(\mathrm{P}<0.05)$, reduced acetate production $\left(\mathrm{mmol} \cdot \mathrm{day}^{-1}\right)$ in the high forage diet. Nevertheless, the molar proportions $(\mathrm{mol} \%)$ of acetate were significantly reduced by all three oils, mainly by LO and FO. Propionate $\left(\mathrm{mmol} \cdot \mathrm{day}^{-1}\right)$ was significantly increased with $\mathrm{FO}$ and $\mathrm{LO}$ and its molar proportions (mol\%) were increased with LO, FO, RO by about $8.8 \%(\mathrm{P}<0.05), 0.9 \%(\mathrm{P}<0.05)$ and $6.7 \%(\mathrm{P}<0.005)$, respectively, in comparison with the control diet. Only fish oil decreased n-butyrate production and its molar proportion in the diet used (Table 1). The calculated acetate to propionate production showed a significantly (LO, FO) or slightly (RO) decreased $\mathrm{A} / \mathrm{P}$ ratio in this experiment. The energetic efficiency of VFA (E,\%) was significantly increased mainly with FO, LO in comparison with the control. Rapeseed oil only slightly (NS) increased E (\%). This was evoked by the increase in the mol $\%$ of propionate and decrease of the mol $\%$ of n-butyrate in the oil-supplemented diets (Table 1). Several reports have indicated a beneficial effect of PUFA on microbial protein synthesis (Broudiscou et al., 1994), others, a negative effect (Czerkawski et al., 1975). According to our results, the oils supplemented to the high forage diet did not affect OMF, $\mathrm{N}_{\mathrm{M}}$, or efficiency of microbial protein synthesis (EMS).

\section{CONCLUSIONS}

Supplementation of (LO, RO, FO) at 5\% in DM to feed rations (fresh lucernemaize $(60: 40 \%)$ did not affect some parameters of rumen fermentation ( $\mathrm{pH}$, dry matter, detergent fibre digestibility, or total VFA production); LO and FO significantly reduced the $\mathrm{mol} \%$ of acetate, $\mathrm{n}$-butyrate, $\mathrm{A} / \mathrm{P}$ ratio and increased the $\mathrm{mol} \%$ of propionate, while RO slightly (NS) affected these parameters of rumen fermentation; LO, RO, FO supplemented to a high forage diet did not affect OMF, $\mathrm{N}_{\mathrm{M}}$, or EMS.

\section{REFERENCES}

Broudiscou L., Pochet S., Poncet C., 1994. Effect of linseed oil supplementation on feed degradation and microbial synthesis in the rumen of ciliate-free and refaunated sheep. Anim. Feed Sci. Tech. 49, 189-202

Czerkawski J.W., Christie W.W., Breckenridge G., Hunter M.L., 1975. Changes in the rumen metabolism of sheep given increasing amounts of linseed oil in their diet. Brit. J. Nutr. 34, 25-44

Hristov A.N., Ivan M., McAllister T.A., 2004. In vitro effects of individual fatty acids on protozoal numbers and on fermentation products in ruminal fluid from cattle fed a high- concentrate, barleybased diet. J. Anim. Sci. 82, 2693-2704

Jalč D., Čertík M., 2005. Effect of microbial oil, monensin and fumarate on rumen fermentation in artificial rumen. Czech J. Anim. Sci. 50, 467-472

Jalč D., Potkański A., Szumacher-Strabel M., Kowalczyk J., Cieślak A., 2006a. The effect of a forage diet and different fat sources on rumen fermentation in vitro. J. Anim. Feed Sci. 15, Suppl. 1, 129-134

Wachira A.M., Sinclair L.A., Wilkinson R.K., Hallett K., Enser M., Wood J.D., 2000. Rumen biohydrogenation of $n-3$ polyunsaturated fatty acids and their effects on microbial efficiency and nutrient digestibility in sheep. J. Agr. Sci. 135, 419-428 